\title{
KAJIAN CAHAYA PERSPEKTIF FISIKA DAN TASAWUF
}

\author{
Agus Mufyono \\ Fakultas Sain dan Teknologi Universitas Islam Negeri (UIN) Malang \\ Jl. Gajayana 50 Malang 65144 Telp.0341-551354,558882 \\ Faks.0341-572533,0341-558882 e-mail: gusmul_75a@yahoo.co.id
}

\begin{abstract}
Light plays vital role in human life, without which objects will be impossible to see and the beauty of world and universe will not be unseen. The theory of light merely describes its nature and leaves the essence unknown. Samuel Johnson maintains that light is known to everybody, but it is not easy to reveal its reality. Light of universe is the light of God shining upon the heart of His open-hearted servants dan embellishing His pious and devoted ones. Therefore, the heart of servant who is endowed with God's light will glow like the sun shining the moon. God's light in human heart surpasses tender light of the moon, becomes cure and draw near to God.
\end{abstract}

Key words: light, tasaunf

\section{Pendahuluan}

Cahaya memegang peranan penting dalam perikehidupan manusia. Tanpa cahaya kita tidak dapat melihat benda-benda di sekitar kita. Ini berarti bahwa tanpa cahaya, kita tidak dapat menikmati keindahan dunia dan alam semesta. Manusia banyak belajar dari alam sekitamya. Lebih dari $70 \%$ 
pengetahuan manusia diperoleh melalui indera mata atau penglihatan. Sedangkan penglihatan tidak akan berfungsi tanpa ada cahaya.

Menurut Newton cahaya adalah partikel-partikel yang sangat kecil sangat ringan dan bergerak dengan sangat cepat yang dipancarkan dari sumbernya ke segalah arah. Menurut Huygens bahwa cahaya adalah gelombang yang merambat dengan cepat. Menurut Zeeman bahwa cahaya dapat dipengaruhi medan magnet yang kuat, menurut Strok cahaya juga dipengaruhi oleh medan listrik yang kuat, menurut Planck cahaya adalah pancaran energi dalam bentuk paket-paket kecil yang disebut kuanta. Kemudian menurut Einstein bahwa cahaya bersifat dualistis artinya cahaya memiliki sifat sebagai partikel maupun sifat sebagai gelombang. Jadi apa sebenarnya hakikat cahaya?

Allah berfirman dalam al-Qur'an surat an-Nur ayat 35

Allah memberi cahaya langit dan bumi. Umpamanya cahayanya kepada orang yang beriman, seperti sebuah lobang di dinding rumah di dalamnya pelita, pelita itu di dalam gelas. Gelas itu kelihatannya laksana bintang yang berkilau-kilauan di langit. Pelita itu dinyalakan dengan minyak kayu yang berkat,yaitu minyak zaitun, yang tiada tumbuh di timur dan tiada pula di barat, hampir minyak itu bercahaya dengan sendirinya, meskipun tiada disentuh api. Cahaya di atas cahaya. Allah menunjuki orang-orang yang dikehendakiNya kepada cahayaNya itu. Allah menunjukkan beberapa perumpamaan bagi manusia; dan Ia mengetahui tiap-tiap sesuatu. (QS. an-Nur: 35)

Mempelajari hakikat cahaya sama sulitnya dengan mempelajari hakikat manusia. Tulisan ini membahas Cahaya dalam perpektif Fisika dan Tasawuf

\section{Cahaya Perspektif Fisika}

\section{a. Teori Cahaya}

Cahaya memegang peranan penting dalam perikehidupan manusia. Tanpa cahaya kita tidak dapat melihat benda - benda disekitar kita. Tanpa 
cahaya tidak dapat menikmati keindahan dunia dan alam semesta. Apa sebenarnya cahaya?

Orang yunani kono percaya bahwa mata manusia memancarkan seberkas cahaya sewaktu melihat, cahaya itu mengenai benda kemudian memantul balik ke mata. Kira kira pada $1000 \mathrm{M}$, Ibn Haitam menyatakan bahwa mata menerima cahaya dari luar bukan memancarkan cahaya.

Beberapa teori tentang cahaya adalah sebagai berikut, Menurut Sir Isaac Newton (1642-1727) bahwa cahaya adalah partikel-partikel yang sangat kecil sangat ringan dan bergerak dengan sangat cepat yang dipancarkan dari sumbernya ke segalah arah. Bila partikel-partikel sampai ke mata, maka kita dapat melihat benda. Partikel sangat kecil itu disebut "corpus", maka teori ini disebut teori corpuskula. Berbeda dengan pendapat Newton, seorang Belanda bemama Christian Huygens (1678) berpendapat bahwa cahaya adalah gelombang yang merambat dengan cepat. Medium yang dipakai untuk perambatan gelombang cahaya itu menurut Huygen adalah eter. Teori ini disebut teori gelombang.

Maxwell (1857-1894) ternyata mendukung teori gelombang dengan menyempurnakan dengan pernyataan bahwa kecepatan merambat gelombang elektromagnet yaitu sebesar $3 \times 10^{8} \mathrm{~m} / \mathrm{s}$.

Seorang ilmuwan bangsa jerman bernama Heinrich Hertz (1887) berhasil menunjukkan bahwa gelombang elektromagnetik adalah suatu gelombang yang merambat secara transfersal, hal ini sesuai dengan sifat cahaya yang dapat dipolarisasikan.

Zeeman (1852-1943) seorang ilmuwan bangsa Belanda melalui percobaannya berhasil menyimpulkan bahwa ternyata cahaya dapat dipengaruhi oleh medan magnet yang kuat. Demikian pula J. Strok (18741957) ilmuwan bangsa Jerman, berhasil membuktikan bahwa cahaya dapat dibelokkan oleh medan listrik yang kuat.

Kemudian Max Planck (1858-1947), melalui percobaannya berkesimpulan bahwa cahaya tidak lain adalah pancaran energi dalam 
bentuk paket-paket kecil yang disebut kuanta. Teori ini yang disebut sebagai teori kuantum cahaya. Kuantum energi cahaya lazim juga disebut "photon".

Terakhir Albert Einstein (1879-1955), seorang Yahudi berkebangsaan Amerika, berhasil menemukan gejala fotolistrik. Dengan ditemukan adanya gejala fotolistrik maka dapat dijelaskan bahwa cahaya bersifat dualistis, artinya cahaya memiliki baik sifat sebagai partikel maupun sifat sebagai gelombang.

Dari beberapa teori tersebut terlihat lebih menjelaskan tentang sifat dari cahaya masih belum menjelaskan secara detil tentang hakikat dari cahaya. Seperti halnya yang telah dikatakan oleh "Samuel Johnson's" bahwa kita semua tahu tentang cahaya, tetapi dakkah mudah untuk menceritakan apakah cahaya tersebut ?"

\section{b. Sejarah pengukuran kelajuan cahaya}

Pada tahun 1675 Ole Roemer sarjana astronomi Denmark mendapatkan laju cahaya $2 \times 10^{8} \mathrm{~m} /$ det. Kemudian kira-kira tahun 1725 James Bradley seorang sarjana Astronomi Inggris mendapatkan laju cahaya kira-kira $3 \times 10^{8} \mathrm{~m} /$ det. Pada tahun 1849 Hippolyte Louis Fizeau seorang Fisikawan Prancis mendapatkan laju cahaya sebesar 3,13 x 108 $\mathrm{m} / \mathrm{det}$. Tahun 1926 Michelson dari Amerika mendapatkan laju cahaya 2,998 x 108 $\mathrm{m} /$ det. Inilah sekelumit tentang sejarah pengukuran laju cahaya.

Laju cahaya menurut satandar internasional yang telah ditentukan oleh berbagai instansi adalah sebagai berikut: Menurut US National Bureau of Standards, C = $2997924574+0.0011 \mathrm{~km} /$ det; menurut The British National Physical Laboratory, C $=299792.4590+0.0008 \mathrm{~km} / \mathrm{det}$; Menurut Konferensi ke-17 penetapan ukuran dan berat standard " satu meter adalah jarak tempuh cahaya dalam ruang vacuum selama jangka waktu 1/ 299792458 detik" (Halliday, 1994: 586).

\section{c. Sifat-Sifat Cahaya}

Cahaya adalah gelombang, yaitu gelombang elektromagnetik. Ciri utama dari gelombang adalah gelombang tidak pernah diam, jadi cahaya 
selalu bergerak. Benda-benda yang sangat panas, seperti maîahari dan filamen lampu listrik memancarkan cahayanya sendiri merupakan sumber cahaya. Bulan bukan merupakan sumber cahaya, bulan hanya memantulkan cahaya yang diterimanya dari matahari. Jadi cahaya selain dipancarkan cahaya dapat dipantulkan.

Cahaya juga dapat dibelokkan atau dibiaskan. Jika cahaya melewati bidang batas dua medium, maka cahaya dari satu medium ke medium lainnya akan mengalami pembiasan. Cahaya juga dapat terdispersi. Seberkas cahaya putih yang dijatuhkan pada permukaan prisma akan terurai menja komponen-komponen warna (akan dijelaskan kemudian). Komponen warna itu dikenal dengan sebutan pelangi. Cahaya juga dapat berinterferensi. Perpaduan dua gelombang cahaya akan dapat menghasilkan sebuah gelombang baru.

\section{d. Sumber Cahaya}

Sumber cahaya dapat dikelompokkan menjadi 2 yaitu sumber cahaya alami dan sumber cahaya buatan. Sumber cahaya alam seperti matahari dan bintang. Sumber ini tidak dapat kita kendalikan. Sedangkan sumber cahaya buatan seperti lampu listrik dan nyala lilin dapat dikendalikan, karena dapat dinyalakan atau dimatikan sesuai dengan kemauan kita.

\section{e. Cahaya dan Warna}

Cahaya tampak adalah cahaya yang terlihat oleh mata kita. Sumber cahaya tampak tergantung pada gerakan elektron. Elektron dalam atom dapat naik dari keadaan energi rendah ke keadaan energi tinggi dengan beberapa cara. Elektron yang kembali ke tingkat energi normal akan melepaskan energi dalam bentuk cahaya yang terlihat (berwarna).

Cahaya merupakan radiasi gelombang elektromagnetik yang mempunyai panjang gelombang antara $400 \mathrm{~nm}$ sampai $700 \mathrm{~nm}$ yang dikenal sebagai cahaya tampak. Jadi retina mata manusia hanya dapat mendeteksi radiasi gelombang elektromagnetik cahaya tampak dan dicatat oleh otak sehingga sesuatu dapat dilihat sebagai warna.

Ulul Albab, Vol. 9 No. 1, 2008 
Cahaya putih yang biasa kita lihat (disebut juga cahaya tampak atau visible light) terdiri dari semua komponen warna dalam spektrum di atas tentu saja ada komponen lain yang tidak terlihat, disebut invisible light. Jadi warna merah, jingga, kuning, hijau, biru, nila, ungu berasal dari cahaya putih. Alat paling sederhana yang sering dipakai untuk menguraikan warna putih adalah prisma kaca. Selain prisma tetesan air dari air hujan juga dapat berfungsi menguraikan cahaya putih. Ketika seberkas cahaya putih mengenai setetes air, tetesan air ini berprilaku seperti prisma, dapat menguraikan cahaya putih menjadi warna-warna yang kita kenal sebagai pelangi. Agar lebih jelas di bawah ini menunjukkan panjang gelombang dan warná

Harun Yahya secara detil menulis tentang terjadinya warna, bahwa untuk menjadi wama melalui tahap-tahap berikut. Pertama: yang diperlukan untuk pembentukan warna adalah keberadaan cahaya (light). Dalam hal ini, ada baiknya memulai dengan mencermati sifat-sifat cahaya yang berasal dari matahari. Cahaya dari matahari yang datang ke bumi harus memiliki panjang gelombang tertentu untuk menghasilkan warna. Bagian cahaya ini, yang dikenal sebagai "cahaya tampak", cahaya lain yang dipancarkan.

Kemudian, sebagian besar sinar (rays) yang dipancarkan matahari ke seluruh jagat raya mengandung beberapa karakteristik yang membahayakan mata. Oleh karena itu, cahaya yang tiba ke bumi harus dalam bentuk tertentu sehingga dapat ditangkap mata dengan mudah dan tidak membahayakannya. Untuk itu, cahaya ini harus melewati suatu filter. Filter raksasa ini adalah "atmosfer" yang menyelimuti bumi.

Cahaya yang melewati atmosfer disebarkan ke seluruh permukaan bumi, dan ketika mengenai objek, cahaya ini dipantulkan. Objek tempat cahaya jatuh harus dari jenis yang tidak menyerap cahaya, tetapi memantulkannya. Dengan kata lain, kualitas struktur objek harus selaras juga dengan cahaya yang mencapai bumi agar warna dapat terbentuk. Kondisi ini juga terpenuhi dan gelombang cahaya baru dipantulkan dari objek yang terkena cahaya matahari. Syaratpenting berikutnya dalam proses

Ulul Albab, Vol. 9 No. 1, 2008 
pembentukan warna adalah keberadaan alat yang dapat mengindra gelombang cahaya, yaitu mata. Sangat penting bahwa gelombang cahaya juga selaras dengan organ penglihatan. Sinar yang datang dari matahari harus melewati lensa dan lapisan-lapisan mata dan kemudian diubah menjadi impuls-impuls saraf di dalam retina. Sinyal ini kemudian harus diangkut ke pusat penglihatan pada otak, yang bertugas menginterpretasikan pandangan. Selanjutnya terakhir yang harus dipenuhi agar kita dapat 'melihat' warna. Tahap akhir dalam pembentukan warna adalah interpretasi sinyal listrik sebagai "wama" oleh sel saraf yang sangat khusus di dalam pusat penglihatan otak (Harun Yahya, 2004).

Demikianlah, untuk pembentukan satu warna saja, diperlukan urutan proses yang sangat detail dan saling tergantung. Dengan warna hidup menjadi lebih indah, lebih dapat dinikmati. Jadi cahaya sangat berperan penting dalam kehidupan ini. Tidak hanya untuk menerangi alam semesta tetapi juga memberi keindahan bagi alam ini.

\section{f. Matahari sebagai Sumber Cahaya}

Matahari dan bintang-bintang merupakan sumber cahaya alami. Matahari disebut juga bintang yang paling dekat dengan bumi yang memberikan energi untuk mempertahankan kehidupan di bumi. Energi diciptakan pada bagian dalam matahari, kemudian dijalarkan ke permukaan dan diradiasikan ke dalam ruang angkasa.

Dari beberapa literatur salah satunya menurut Bayong, bahwa sekitar $99 \%$ radiasi elektromagnetik yang dipancarkan oleh matahari terletak pada daerah 0,15 dan $4,0 \mu \mathrm{m}$. Distribusinya adalah $9 \%$ ultraviolet (ultra ungu), $45 \%$ radiasi tampak (cahaya tampak) dan $46 \%$ infra merah. Energi ini dijalarkan ke permukaan bumi dalam bentuk gelombang elektromagnetik (Bayong, 2006: 80).

Darimana energi itu? Energi yang diradiasikan akibat transformasi hidrogen menjadi helium yang kemudian menghasilkan energi. 


$$
4_{1} \mathrm{H}_{1}-{ }_{2} \mathrm{He}^{4}+2 \mathrm{e}^{+}+\text {Energi }
$$

Sebagian energi tersebut ditransmisikan ke bumi dengan cara radiasi gelombang elektromagnetik. Radiasi menjalar dengan kecpatan cahaya $\left(3 \times 10^{8} \mathrm{~m} / \mathrm{s}\right)$ dalam bentuk gelombang yang mempunyai panjang gelombang yang berbeda-beda. Peristiwa ini akan berhenti jika hidrogen dalam reaksi inti habis.

Saat cahaya Matahari memasuki atmosfer Bumi, cahaya matahari akan berinteraksi dengan partikel-partikel udara. Partikel di udara, terutama lapisan atas yang dilalui cahaya lebih dulu, didominasi oleh Oksigen (O) dan Nitrogen $(\mathrm{N})$. Interaksi antara cahaya dan materi melibatkan tiga fenomena: absorbsi (penyerapan), transmisi (penerusan), dan refleksi (pemantulan) .

Partikel $\mathrm{O}$ dan $\mathrm{N}$ sangat efektif berinteraksi dengan cahaya dengan panjang gelombang yang rendah dan melewatkan cahaya panjang gelombang yang lebih tinggi. Partikel $\mathrm{O}$ dan $\mathrm{N}$ cendrung menyerap warna ungu terlebih dahulu, kemudian biru, kemudian hijau, dan seterusnya tergantung berapa banyak interaksi yang terjadi. Karena itu jarak tempuh berkas cahaya tersebut mulai dari pertama kali berinteraksi sampai ke mata kita sangat menentukan warna langit yang terlihat oleh mata kita (sehingga langit kadangkala terlihat hitam pada malam hari, biru pada siang hari, maghrib dan subuh tampak merah)

\section{g Cahaya Bintang}

Pada malam hari ketika kita melihat kelangit maka akan kita lihat gemerlap bintang-bintang menambah keindahan di malam hari. Selain membuat indah, bintang juga menjadi tanda arah bagi para pelaut jaman dulu.

Bintang merupakan sumber cahaya. Saat mengamati bintang, yang teramati hanyalah sebuah objek kecil yang hampir mirip dengan noktah 
yang memancarkan cahaya. Kecerlangas bintang dapat dilihat dari pancaran energinya. Semakin besar energi yang dipancarkan, maka bintang tersebut akan semakin terang.

Cahaya bintang menambah keindahan alam menambah ketakjuban kepada Allah. Allah Maha Pencipta segala sesuatu. Mengamati cahaya dari benda langit dapat membedakan apakah itu bintang atau planet. Bagi mata orang awam, seluruh obyek tampak sama, berupa titik cahaya yang bertebaran di langit dan secara umum disamakan sebagai "bintang".

Ada perbedaan mendasar antara planet dan bintang. Salah satunya, bintang memancarkan cahaya sendiri (Matahari adalah sebuah bintang), sedangkan planet terlihat bercahaya karena memantulkan cahaya Matahari (seperti Bulan). Ada beberapa cara membedakan planet dan bintang di langit malam dengan mata telanjang tanpa bantuan alat. Setelah mata telanjang bisa mengenali mana planet dan mana bintang, baru orang dapat meneropong planet yang ingin diamati.

Cahaya planet tampak lebih terang dan ukurannya lebih besar dibandingkan dengan bintang. Hal ini karena letak mereka lebih dekat dibandingkan dengan jarak bintang. Salah satu contoh planet yang paling mudah dikenali adalah Venus. Biasanya tampak sesaat setelah Matahari tenggelam dan menjelang Matahari terbit. Planet Venus sering disebut "Bintang Fajar" atau "Bintang Kejora" karena cahayanya sangat cemerlang. Adapun Planet Mars dapat dikenali dari cahayanya yang berwarna kemerahan.

Cahaya bintang tampak berkelap-kelip, sedangkan cahaya planet cenderung tidak berkelap-kelip. Letak bintang sangat jauh dari Bumi sehingga cahaya yang tiba di permukaan Bumi sudah sangat lemah dan mudah terganggu turbulensi udara di atmosfer. Turbulensi udara ini bisa membelokkan cahaya sehingga cahaya bintang tampak berkelap-kelip. Sedang cahaya dari planet cenderung lebih stabil karena planet lebih dekat sehingga cahaya yang sampai di permukaan Bumi "lebih banyak". Gangguan turbulensi udara di atmosfer juga tak terlalu berpengaruh. 
Apabila pengamatan dilakukan beberapa hari berturut-turut, akan terlihat posisi planet akan berpindah dari hari ke hari (waktu terbit atau tenggelam akan berbeda dari hari ke hari). Planet terlihat bergerak terhadap latar belakang bintang-bintang yang lain.

Hal ini disebabkan gerakan Bumi mengelilingi Matahari sehingga posisi planet-planet itu akan terlihat bergeser pada hari yang berbeda. Karakter ini juga dapat dijadikan patokan untuk membedakan planet dan bintang.

\section{h. Proses Melihat}

Manusia dapat melihat bukan hanya karena mempunyai mata, tetapi yang paling berperan adalah adanya cahaya. Ada mata tetapi tidak ada cahaya, seperti pada ruang gelap meskipun mata terbuka lebar maka tidak akan dapat melihat benda yang ada diruang tersebut. Ada cahaya tetapi tidak punya mata maka juga tidak akan bisa melihat.

Apa yang menyebabkan mata dapat melihat?

Mata, bentuknya seperti bola kecil dilapisi dan lapisan itu mempunyai sifat tak tembus cahaya, lapisan itu disebut skelera. Lapisan tersebut sangat kuat yang berfungsi untuk melindungi mata dari terhadap berbagai pengaruh dari luar. Bagian depan dari lapisan skelera ada selaput bening yang disebut kornea. Ada juga yang disebut iris atau selaput pelangi yaiti selaput yang berlubangditengahnya yang letaknya di depan lensa mata, lubang itu disebut pupil. Selaput pelangi berfungsi mengontro banyak cahaya yang masuk. Pupil terbuka lebar apabila ditempat gelap, tetapi menjadi sempit dan kecil ditempat yang terang.

Selaput pelangi seperti diafragma pada kamera, yaitu mengatur cahaya sebanyak yang diperlukan untuk mata, dan pada saat yang sama memberi suatu fokus yang lebih tajam bila lubang itu kecil. Jadi besamya pupil dengan sendirinya diatur menurut banyaknya cahaya serta tajamnya penglihatan. Rongga bagian dalam mata dilapisi suatu lapisan yang disebut retina. Pada retina terdapat lapisan yang peka terhadap cahaya. Lapisan ini merupakan cabang ujung syaraf penglihatan. Dibelakang iris terdapat lensa mata yang 
terbuat dari bahan seperti kristal yang bersifect lenting !.ensa ini bersifat seperti lensa cembung, oleh karena itu mampu membentuk gambar nyata dari benda yang ada di depan mata. Dibelakang lensa terdapat ruang yang berisi bahan tembus cahaya menyerupai agar-agar.

Di depan lensa terdapat ruang terisi cairan bening. Cahaya yang berasal dari benda yang ada di depan mata mauk lewat kornea dan lensa. Cahaya itu kemudian dibiaskan oleh lensa sehingga terdapat gambar di retina. Cahaya yang membentuk gambar ini merangsang ujung-ujung syarał

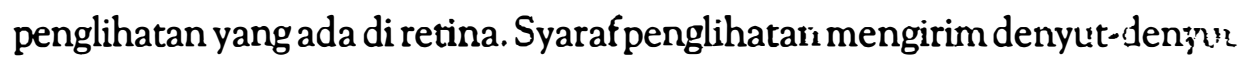
(pulsa) ke otak sehingga dapat kesan melihat benda tersebut. Inilah proses melihat sesuatu.

\section{i. Cahaya dan Kehidupan}

Seperti telah dijelaskan di atas bahwa cahaya sangat berperan dalam kehidupan. Misalnya adalah bagaimana cahaya matahari yang merupakan sumber cahaya di alam semesta ini memberi manfaat dalam kehidupan.

Matahari dan bintang-bintang dan sumber-sumber cahaya lain di alam semesta tidak semuanya memberikan jenis radiasi atau pancaran yang sama. Kembali pada spektrum cahaya, bahwa warna-warna yang kita lihat adalah komponen dari cahaya putih yang disebut cahaya tampak (visible light) atau gelombang tampak. Komponen lainnya adalah cahaya yang tak tampak (invisible light), seperti inframerah (di sebelah kanan wama merah) dan ultraviolet. Jadi, cahaya yang memancar dari sumber (matahari dan bintangbintang) dalam rentang panjang gelombang yang luas. Sinar gamma, yang memiliki panjang gelombang terpendek, karena panjang gelombang pendek maka energinya sangat besar. Panjang gelombang terpanjang adalah gelombang radio. Gelombang radio memiliki energi yang rendah sehingga tidak membahayakan, tetapi kalau terpapar sinar gamma akan berakibat fatal. Jadi sebenarnya cahaya merupakan bentuk radiasi elektromagnetik yang terletak di antara kedua ekstrem panjang gelombang tersebut. 
Sebanyak $70 \%$ radiasi matahari mempunyai panjang gelombang antara 0,3 dan 1,5 mikron, dan dalam pita sempit tersebut terdapat tiga jenis cahaya: cahaya tampak, cahaya infra-merah-dekat, dan cahaya ultraviolet. Radiasi ini sangat tepat untuk kesinambungan kehidupan di alam semesta ini.

Bagaimana dengan panjang gelombang yang lain, seperti sinar gamma, sinar X, dan sinar ultraviolet. Semua radiasi ini memiliki kemampuan membelah atom karena kandungan energinya yang begitu besar. Ketiga radiasi tersebut dapat menyebabkan molekul-molekul khususnya molekul organik terurai. Dampaknya, ketiga radiasi tersebut menguraikan materi pada level atom atau molekul.

Untuk radiasi dengan panjang gelombang lebih panjang dari cahaya tampak, mulai dari infra merah sampai gelombang radio pengaruh radiasinya tidak membahayakan dikarenakan energinya tidak terlalu besar.

Radiasi inframerah matahari adalah radiasi yang membawa energi panas, yang menjaga bumi tetap panas. Radiasi ini juga penting bagi kehidupan seperti halnya cahaya tampak. Gelombang ini tidak tampak sebagai warna tetapi dapat dirasakan. Kalau kita berada dibawah matahari maka kata akan merasakan hangat. Itulah akibat inframerah.

Bagaimana halnya dengan sinar ultraviolet? Sinar ultraviolet berenergi tinggi sehingga dapat merusak sel hidup. Sinar ultraviolet diperlukan untuk pembentukan vitamin $\mathrm{D}$ pada manusia dan binatang bertulang belakang. Jadi dari penjelasan di atas menunjukkan bahwa cahaya begitu pentingnya dalam kehidupan ini.

Masih ada lagi yang penting dipahami tentang peran cahaya, yaitu proses fotosintesis. Sewaktu dalam pelajaran biologi kita mendapatkan penjelasan bahwa apabila tumbuhan tidak melakukan fotosintesis maka tumbuhan akan mati, kalau tumbuhan mati maka tidak ada sumber makanan, sehingga tidak akan ada kelangsungan kehidupan.

Untuk berfotosintesis tumbuhan perlu cahaya. Tanpa cahaya tumbuhan tidak dapat melakukan fotosintesis. Tumbuhan mampu 
melakukan fotosintesis karena molekul klorofil dalam selnya sensitif terhadap cahaya matahari. Namun klorofil hanya mampu menggunakan kisaran panjang gelombang yang sangat terbatas. Dalam proses fotosintesis tumbuhan menghasilkan dua produk: yaitu glukosa, dan juga melepaskan enam molekul oksigen. Jika tumbuh-tumbuhan tidak melepaskan oksigen, maka makhluk hidup yang ada di bumi akhirnya akan menghabiskan semua oksigen dalam atmosfer, dan ini akan menjadi akhir bagi kehidupan. Tumbuh-tumbuhan berperan secara terus-menerus memperbaharui kondisi atmosfer.

Dalam al-Qur'an telah dijelaskan tentang benda-benda yang menge luarkan cahaya sendiri (dalam al-Qur'an menggunakan kata dhiya', seperti matahari. Sedangkan kata nur (cahaya) dan beberapa turunannya menggambarkan makna cahaya yang ditimbulkan akibat pantulan benda yang terkena sinar, seperti bulan. Makna ini dapat kita temukan dalam al-Qur'an:

Dia-lah yang menjadikan matahari bersinar dan bulan bercahaya dan ditetapkan-Nya manzilah-manzilah (tempat-tempat) bagi perjalanan bulan itu, supaya kamu mengetahui bilangan tahun dan perhitungan (waktu). Allah tidak menciptakan yang demikian itu melainkan dengan hak dia menjelaskan tanda-tanda (kebesaran-Nya) kepada orang-orang yang Mengetahui (QS. Yunus: 5)

Dan Allah menciptakan padanya bulan sebagai cahaya dan menjadiknn matahari sebagai pelita? (QS. Nuh: 16)

Dan kami jadikan Pelita yang amat terang (matahari), (QS. an-Naba': 13).

Ayat di atas memberikan definisi yang tepat untuk kata dhiya' (sinar) dan nur (cahaya) yang dalam bahasa arab kedua kata tersebut digunakan untuk menunjuk sesuatu yang memancar dari benda yang terang dan membantu manusia untuk dapat melihat benda-benda yangdilalui pancaran itu. Dalam al-Qur'an kita temukan contoh benda-benda atau gejala-gejala 
lain yang memancarkan sinar seperti barq (kilat), nar (Api) atau zait (minyak). (Pasya, 2004: 100):

Hampir-hampir kilat itu menyambar penglihatan mereka. setiap kali kilat itu menyinari mereka, mereka berjalan di bawah sinar itu, dan bila gelap menimpa mereka, mereka berhenti. Jikalau Allah menghendaki, niscaya dia melenyapkan pendengaran dan penglihatan mereka. Sesungguhnya Allah berkuasa atas segala sesuatu. (QS. alBaqarah: 20)

Perumpamaan mereka adalah seperti orang yang menyalakan api, Maka setelah api itu menerangi sekelilingnya Allah hilangkan cahaya (yang menyinari) mereka, dan membiarkan mereka dalam kegelapan, tidak dapat Melihat (QS. al-Baqarah: 17)

Al-Qur'an juga telah membedakan benda-benda langit yang termasuk kategori dhiya' dan nur antara lain bintang (termasuk dhiya') dan planet (nur).

Dalam arti fisis maupun kiasan, cahaya memegang peran penting bagi manusia. Dalam arti fisis, cahaya adalah bagian dari gelombang elektromagnetik yang sejenis dengan gelombang radio, infra merah, ultra violet, sinar-X, dan sinar gamma. Dalam makna kiasan, cahaya adalah petunjuk Allah atau bahkan dikiaskan sebagai proyeksi dari Allah.

\section{Cahaya Perspektif Tasawuf}

a. Cahaya Menurut Imam Ghozali

Berbicara tentang cahaya menurut al-ghazali dalam kitabnya "Misykat al-Anwar" bahwa cahaya selalu berhubungan dengan indera penglihatan. Ada tiga macam hubungan cahaya dengan indera penglihatan, yaitu:

1. Yang dengan sendirinya tidak bisa dilihat seperti benda hitam dalam gelap. 
2. Yang dengan sendirinya dapat dilihat, akan tétapi dengannya tidak dapat dilihat sesuatu benda lainnya yaitu benda benda yang memancarkan cahaya seperti halnya bintang dan api sewaktu ia belum menyala.

3. Yang dengan sendirinya dapat dilihat dan dengannya dapat pula dilihat benda lain, seperti matahari dan bulan, pelita atau api yang sedang menyala.

Jadi yang disebut cahaya adalah yang ketiga dari pernyataan diatas. Jadi menurut al-Ghazali bahwa nur atau cahaya dapat dikatakan bahwa cahaya yang dengan sendirinya dapat terlihat dan denganya pula dapat dilihat benda benda lain seperti matahari.

Dengan menggunakan istilah cahaya ini sebenarnya lebih mudah dimengerti jika cahaya itu digambatkan dengan sesuatu yang dapat dipandang oleh mata, karena itu cahaya yang sesungguhnya ialah cahaya yang dapat memberi reaksi. Umumnya dinamakan nur dengan cahaya mata yang dapat memperhatikan mereka; yang lemah penglihatannya mengatakan bahwa cahaya-cahaya itu lemah; dan orang yang rabun mengatakan bahwa cahaya dari pandangannya itu telah dilemahkan, sedangkan orang orang buta mengatakan bahwa cahayanya itu telah dipadamkan.

Cahaya badani (jasmaniah)/ mata mempunyai beberapa kekurangan misalnya:

- dapat memandang kepada yang lain tetapi tidak dapat memandang dirinya sendiri

- tidak dapat memandang sesuatu yang sangat jauh, dan yang sangat dekat

- tidak dapat melihat sesuatu dibalik dinding

- hanya dapat melihat sebagian, tidak bisa seluruhnya

- hanya dapat melihat sesuatu yang ada batasnya

- membawa akibat kekeliruan dalam pandangannya karena melihat yang besar seperti kecil, melihat yang jauh sepertinya dekat, asesuatu yang

Ulul Albab, Vol. 9 No. 1, 2008 
diam dianggap bergerak dan sebaliknya sesuatu yang bergerak terlihat diam.

Karena banyak kekurangan seperti yang disebutkan di atas, maka cahaya badani (mata) tidak berhak untuk diberi nama sebagai cahaya. (alGhazali, tt: 192). Ini sejalan dengan konsep fisika, bahwa mata hanya bisa melihat suatu benda kalau ada cahaya. Tanpa cahaya meskipun mata kita normal, tidak akan dapat melihat benda.

Pada diri manusia, yaitu hati manusia terdapat mata cahaya (mata hati) yang diikuti dengan sifat-sifat kesempurnaan, inilah yang kemudian disebut akal, kadang juga disebut ruh, kadang juga disebut jiwa insaniah. Menurut al-Ghazali akallah yang lebih pantas disebut nur (cahaya) dibanding dengan mata, karena akal tidak mempunyai kekurangan yang telah disebutkan di atas.

Ada beberapa hal terkait dengan pengertian mata dan akal, Pertama: mata tidak dapat melihat dirinya sendiri, akan tetapi akal dapat melihat dan mengerti dirinya sendiri dan sifat-sifatnya sendiri. Kedua: mata tidak dapat melihat benda yang sangat dekat atau sangat jauh, sedangkan bagi akal bisa dijangkau. Ketiga: mata tidak dapat melihat apa yang berada dibelakang dinding tetapi bagi akal hal itu masih bisa dijangka. Keempat: mata hanya dapat melihat bagian-bagian luar dari permukaan benda, hanya bisa melihat dhahirnya saja, tidak bisa melihat bagian-bagian yang ada didalamnya, tidak bisa melihat inti hakikatnya. Pat masuk ke dalam dasar batin bagian dalam dari benda bahkan dapat masuk dalam inti hakikatnya. Kelima: mata hanya dapat melihat bagian-bagian dari apa yang berwujud. Keenam: mata sering menganggap yang besar itu kecil, misalnya matahari hanya terlihat sebesar balon padahal matahari lebih besar daripada Bumi. (al-Ghazali, tt: 194).

Jadi apa yang dimaksud al- Ghazali bahwa jangan terlalu menggantungkan pada mata, menggantungkan pada pengamatan saja, 
karena mata atau hasil pengamatan kita sangat terbatas. Hendaknya sangat perlu untuk menngunakan secara optimal dari potensi akal.

\section{B. Cahaya Akal}

Dari apa yang dijelaskan di atas menurut al-Ghazali bahwa akal yang lebih pantas disebut cahaya bukan mata. Akal yang mendapatkan cahaya dari sumber segala sumber cahaya.

Menurut Muhammad Mahdi al-Ashify dari kitabnya yang berjudul al-Hawa fi Hadis ahl Al-Bait bahwa akal mempunyai tiga peran dalam kehidupan manusia, yaitu 1) mengenal Allah swt ialah pangkal dan titik tolak tugas akal; 2) ketaatan mutlak kepada segala perintah Allah. Mengenal rububiyah Allah dengan baik akan menghasilkan ketaatan dan Ubudiyah; 3) Taqwa kepada Allah.

Rasulullah bersabda: akal terbagi menjadi tiga bagian, dan barang siapa menyandangnya maka sempurnalah akalnya, dan yang tidak, dia tidak berakal. 1) makrifat yang benar tentang Allah; 2) Ketaatan yang mutlak kepada Allah;3) Kesabaran yang mendalam untuk menjalankan perintahnya (al-Ashify, 1997: 72).

\section{Cahaya Matahari dan Cermin}

Suhrawardi, sufi yang dikenal sebagai Syaikh al-Isyraq, membuat perumpamaan tentang cermin dan matahari. Ketika cahaya matahari mengenai cermin maka cahaya matahari akan diserap oleh cermin itu dan dipantulkannya kembali. Seandainya cermin mampu melihat ke dalam dirinya, ia akan terkejut dan mengira bahwa dirinya-lah matahari itu karena betapa kuatnya cahaya matahari tersebut.

Suhrawardi menanalogkan Manusia sebagai cermin sedangkan Allah diumpamakan sebagai matahari. Ketika manusia mampu mensucikan dirinya dan membersihkannya hatinya, maka ia layak diserupakan dengan cermin. Ketika manusia menjumpai tanda-tanda kekuasaan ilahi, ia menerima cahaya ilahi yang dipancarkansedemikian kuatnya ke dalam dirinya. Ia serap cahaya 
ilahi itu lalu ia pantulkan kembali. Ketika manusia mampu menyerap dan memantulkan kembali cahaya ilahi itu, hidup kita akan terus diterangi oleh cahaya ilahi. Manusia yang sudah mencapai tahap itu akan menebarkan berkah pada setiapsudut yang menerima pantulan cahaya ilahi dari "cermin". nya. Ia mampu sebarkan rahmat disekelilingnya.

Nabi Muhammad adalah contoh terbaik dari perumpamaan di atas. Cahaya ilahi yang diserap Nabi Muhammad saw dipantulkannya ke seluruh alam semesta. Oleh karena itu, kehadiran Nabi Muhammad mampu menebarkan rahmat ke seluruh alam semesta (rahmatan lil 'alamin).

\section{d. Matahari Hati \\ Kitab al-Hikam karya besar Syaik}

Akhmad Atailah menjelaskan Allah swt menerangi alam dengan cahaya makhluk-Nya dan menerangi hati manusia dengan sifat-sifat-Nya. Oleh karena itu, cahaya alam bisa terbenam, akan tetapi cahaya hati dan kegaiban hati tidak bisa terbenam. Seperti kata penyair, "Sesungguhnya matahari terbenam di waktu malam, sedang matahari hati tidak pernah terbenam."

Cahaya bagi alam semesta, adalah cahaya Allah yang menerangi hati para hamba yang mengetahui kebenaran, dan menghiasi batin hamba yang saleh dan taat. Oleh karena itu, hati hamba yang telah mendapat cahaya Ilahiyah, tidak pernah redup dan selamanya akan bersinar, seperti matahari menyinari rembulan yang menyinarkan cahaya sepanjang malam. Cahaya itu memberi ketenangan dan keteduhan di hati. Cahaya dari Allah yang menyelusup masuk ke dalam hati insan melebihi sejuk sinar rembulan, memantulkan penawar kedalam jiwa manusia sehingga bertambah akrablah sang hamba dengan al-Khaliq.

Cahaya-cahaya Allah yang berupa sifat-sifat Allah yang suci dan mulia bersinar di dalam hati sanubari manusia, memperteguh keyakinan sehingga si hamba mendapat kesejukan dan kenikmatan dalam jiwanya. Merasakan kesejukan dan kelezatan iman dalam jiwa akan menumbuhkan ketenangan 
yang sangat diperlukan oleh jiwa yang resah gelisah. Jiwa akan menjadi sakinah dan mutmainah setelah mendapat cahaya yang menerangi hidup manusia lahir dan batin. Ketenangan jiwa yang mendapat cahaya dari Allah swt, akan memberi kekuatan, keteguhan dalam mempertahankan hidup suci dalam ketaatan, serta memperkokoh (istiqamah) mempertahankan keimanan dan keyakinan.

Allah telah menerangi alam semesta ini dengan cahaya matahari, bulan dan bintang. Cahaya itu merupakan berkah dari Allah. Akan tetapi memancarkan cahaya dari kemuliaan sifat-sifat-Nya kedalam hati sanubari manusia. Itulah yang abadi, tidak pernah redup, tidak pernah mati, Matahari yang bersinar di langit bisa redup, akan tetapi matahari yang bersinar dihati tak pernah redup. Itulah cahaya Allah yang memantul ke hati hamba-hamba yang tekun beribadah.

\section{e. Manusia Membutuhkan Cahaya}

Manusia membutuhkan cahaya untuk membantu mengetahui jalan yang harus ditempuh, dan menuntun dalam perjalanan menuju Allah swt. di tengah kegelapan-kegelapan alam materi yang berlapis-lapis; kegelapan yang ada dalam diri manusia itu sendiri maupun kegelapan yang ada di sekelilingnya. Dua kegelapan ini, yang satu lebih gelap dari yang lain. Tanpa cahaya, manusia tidak akan mengetahui jalan dan tidak akan dapat menuju Allah.

Sumber dari segala sumber cahaya yang dimaksud adalah Allah. cahaya ini menyebar menjadi cahaya-cahaya. Cahaya-cahaya ini pada haqiqatnya, merupakan bagian dari cahaya Allah, mempunyai fungsi dan peranan yang sama, yakni membantu manusia untuk mengetahui jalan yang lurus dan benar, dan menuntunnya untuk sampai ke kesempurnaan.

Kitab-kitab Allah dan para nabi adalah cahaya-cahaya Ilahi yang menyinari kegelapan-kegelapan diri manusia dan dunia. Allah berfirman, 
Hai manusia, Sesungguhnya Telah datang kepadamu bukti kebenaran dari Tuhanmu. (Muhammad dengan mukjizatnya) dan Telah kami turunkan kepadamu cahaya yang terang benderang (Al Quran). (QS. al Nisa': 174)

\section{f. Cahaya al-Qur'an}

Al-Qur'an merupakan cahaya yang diturunkan Allah:

Maka berimanlah kamu kepada Allah dan rasul-Nya dan kepada cahaya (al-Quran) yang Telah kami turunkan. dan Allah Maha mengetahui apa yang kamu kerjakan (QS. at-Taghabun: 8)

Al-Qur'an dapat membimbing hamba-hamba yang dikehendaki-Nya.

Dan Demikianlah kami wahyukan kepadamu wahyu (al-Quran) dengan perintah kami. sebelumnya kamu tidaklah mengetahui apakah al-Kitab (al-Quran) dan tidak pula mengetahui apakah iman itu, tetapi kami menjadikan al-Quran itu cahaya, yang kami tunjuki dengan dia siapa yang kami kehendaki di antara hamba-hamba kami. dan Sesungguhnya kamu benar- benar memberi petunjuk kepada jalan yang lupus (QS. ath-Thuur: 52).

Al-Quran itu pula yang akan mengeluarkan manusia dari kegelapan aqidah kepada cahaya:

Dialah yang menurunkan kepada hamba-Nya ayat-ayat yang terang (al-Quran) supaya dia mengeluarkan kamu dari kegelapan kepada cahaya. dan Sesungguhnya Allah benar-benar Maha Penyantun lagi Maha Penyayang terhadapmu. (QS. al-Hadiid: 9)

\section{g Hakikat Cahaya dan Manusia}

Bahwa cahaya dapat dikatakan sebagai partikel atau pada saat lain bisa dikatakan sebagai gelombang. Hal ini menarik kita pelajari karena hakikat manusia juga mempunyai hal yang sama. Maksudnya bahwa menurut Ibn Arabi bahwa manusia mempunyai aspek al-haqq dan al-khalq. 
Al-Haqq merupakan aspek batin dan al-khalq aspek lahir. Pada hakikatnya segala realitas hádala satu.

Aspek lahir yakni alam empiris merupakan tempat tajalli dan sifatsifat Tuhan menurut Ibn Arabi merupakan aspek batin. Wujud hakiki yang sebenarnya adala wujud Allah (Kholil, 2007: 379).

Kembali pada konsep bahwa cahaya bisa sebagai partikel dan juga bisa sebagai gelombang. Konsep ini dalam Fisika juga dapat berlaku pada semua materi. Manusia juga dapat bersifat sebagai partikel yang menurut Ibn Arabi aspek lahir, pada saat lain juga manusia bersifat sebagai gelombang yang menurut Ibn Arabi aspek batin.

Menurut Ibn Arabi wujud alam empiris tidak mempunyai makna secara hakiki. Namun demikian, Allah sendirilah yang menghendaki kemunculannya. Alam ini dimunculkan Allah karena Ia ingin melihat citra diri-Nya melalui makhluk yang menjadi cermin asma dan sifat-sifat-Nya. Allah dapat melihat citra-Nya yang sempurna pada Insan Kamil. Kesempumaanitu dalam konsep Ibn Arabi karena Nur Muhammad (al-haqiqah al-Muhammadi) yang dipandang sebagai tempat tajalli Allah (Kholil, 2007: 379).

Menurut Ibn Arabi juga dikatakan bahwa manusia sebenarnya adalah ruh alam dan alam adalah jasad. Jika kita memperhatikan alam tanpa manusia, niscaya akan menemukan seperti tubuh yang tidak berbentuk tanpa ruh. Kesempurnaan alam karena manusia seperti kesempurnaan jasad karena ruh. Manusia ditiupkan ke dalam tubuh alam. Karena itu ai adalah tujuan alam (Azhari, 1995: 131).

Alam adalah cermin bagi Allah. Cermin awalnya buram, tidak bening, sehingga tidak dapat memantulkan kesempurnaan Allah. Maka Allah tidak dapat dikenal. Sedangkan tujuan penciptaan alam, adalah supaya Tuhan dikenal melalui alam, yang merupakan cermin bagi-Nya. Manusia merupakan tujuan alam atau sebagai tujuan terakhir bagi penciptaan alam, yaitu bahwa manusia adalah perantara bagi perealisasian tujuan karena Allah menciptakan alam supaya melaluinya Dia dikenal. 


\section{h. Cahaya Manusia}

Manusia untuk bisa bertemu dengan dzatnya Allah pasti akan bertemu dengan cahaya ilahi terlebih dahulu jika manusia mempunyai niatan kuat untuk bertemu sebab dalam perjalanan untuk menemukan pencerahan itu manusia akan banyak menemui sesuatu yang irasional di luar kendali kesadarannya. Cahaya ilahi itu ada berbagai macam bentuknya bisa berupa agama dan ilmu. Jika ilmu bisa dicerap melalui kesadaran yang rasional akan tetapi agama tidak melalui kesadaran artinya manusia akan banyak dikendalikan oleh cahaya yang ada di luar kendalinya.

Tempat cahaya itulah berada didalam hati manusia. Cahaya yang keluar dari hati itu lebih kuat bila dibandingkan dengan cahaya yang keluar dari bintang, bulan dan matahari.

$$
\text { مطا لع اللا نوا ر القلوب و الأسرا ر }
$$

"Tempat terbitnya berbagai cahaya ilahi itu berada dalam hati manusia dan rahasia-rahasianya"

Orang yang telah mendapatkan cahaya keyakinan tersebut melihat akhirat seakan-akan dekat atau sudah dihadapan mereka bersiap-bersiaga untuk menuju kesitu dengan rasa riang gembira. Dan melihat dunia ini seakan-akan gelapgulita bahkan menghampiri kerusakan. Dengan demikian ia hdup di dunia ini bergegas-gegas untuk menuju akhirat (alam baqa') yang kekal selamanya. Kalau ada orang yang mempunyai hati demikian artinya ia menganggap dunia tempat kerusakan dan bencana, berarti orang tersebut benar-benar hatinya telah mendapat pelita yang terang yaitu cahaya keimanan.

"Sesungguhnya cahaya keyakinan jika masuk kedalam hati, maka menjadi lapanglah dadanya. Ketika Nabi saw ditanya "Ya Rasulullah? "Apakah yang demikian itu ada tanda-tandanya? Rasulullah saw menjawab "ya, yaitu merenggangkan dari dunia tipuan, condong kembali kepada rumah yang abadi, serta mempersiapkan diri untuk mati sebelum mati itu datang" 
Akan tetapi sebenarnya bisa ditelusuri secara garis besar ada beberapa fase pengenalan manusia terhadap Tuhannya yang pertama adalah dimulai ketika manusia bertanya pada diri sendiri. Fase ini ada pintu gerbang manusia menuju ke alam atau dimensi metafisika (di luar dirinya). Pada fase ini mayoritas manusia pasti akan melakukan melakukan proses intropeksi dari dalam diri sendiri, hal itu mereka lakukan karena manusia memiliki potensi mengoreksi segala sesuatu yang dia hadapi. Karena itu ketika manusia merenung seorang diri, secara tidak sadar dia sudah melakukan pengkajian obyek sesuatu yang ada di luar dirinya bisa jadi hasil bayangan (proyeksi) pengalamannya yang sudah ia lalui lalu ia renungkan dalam dunia renungan (ide), bisa juga berisi muatan obyek yang ia andaikan sendiri, artinya obyek yang ia ciptakan sendiri menjadi sesuatu yang ia kaji dalam dunia renungan (ide), dalam bahasa psikologi mungkin ini yang disebut sebagai imaginasi, fantasi atau yang lainnya.

Setelah fase ini manusia mulai mengenal obyek yang ada di luar dirinya dengan memakai kesadaran dan nalar inderawinya sebagai seorang manusia. Manusia mulai mempercayai Tuhan tapi sebatas nalar inderawinya yaitu mempercayai apa yang sudah dia dengar dan pelajari dari orang-orang yang memberikan pengetahuan tentang Tuhan. Kesadarannya seperti robot yang terkendalikan oleh sebuah pengendali. Dia mengenal Tuhan atas dasar dikendalikan oleh sebuah kekuatan yang ada di luar kemampuan nalar berfikimya. Lantas dia yakin dan memproyeksikan sosok Tuhan dalam dirinya sendiri dan dia sembah. Manusia pada fase ini sebenarnya masih pada fase berimajinasi tentang Tuhan.

Fase selanjutnya adalah ketika manusia mulai dalam keadaan mencari sosok Tuhan yang sebenarnya. Tahap pertama adalah dia mencari dengan memakai kesadaran inderawinya seperti yang dilakukan oleh Nabi Ibrahim ketika mempercayai bulan, matahari adalah Tuhnnya. Akan tetapi ketika nalar kesadarannya sudah mentok tentang Tuhan mulailah manusia mempercayai dunia ghaib.

Dunia ghaib adalah dunia yang bisa dicapai oleh manusia ketika dia munculkan (aktualkan) potensi ruhaniahnya secara penuh artinya ketika 
manusia mempercayai dunia ghaib, manusia akan melakukan upaya atau rekayasa dengan menciptakan ritual-ritual tertentu agar dia bisa mencapai pengetahuan metafisika tersebut dan pada akhirnya dia percaya pada Tuhan. Al-Qur'an sendiri juga searah dengan pandangan tersebut.

(yaitu) mereka yang beriman kepada yang ghaib, yang mendirikan shalat, dan menafkahkan sebahagian rezki yang kami anugerahkan kepada mereka. (QS. al-Baqarah: 3).

Dalam ayat tersebut dijelaskan bagaimana manusia itu memang harus mempercayai alam ghaib sebelum bertemu dan mempercayai Allah, karena cahaya hati itu sumbernya dari gudang (tempat) ghaib.

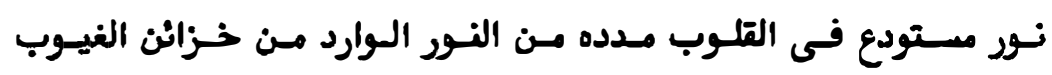

"Cahrya yang tersimpan didalam hati itu datangnya dari cahaya yang datangnya langsung dari gudang-gudang (tempat-tempat) keghaiban"

Cahaya-cahaya ilmu ma'rifat dan cahaya tauhid itu akan bertambah sinarnya yang sumbernya langsung dari nur yang berasal dari gudang ghaib. Allah menerangi segala benda yang lahir ini dengan cahaya benda ciptaanNya, dan Allah menerangi hati batin itu dengan cahaya sifat-sifatNya.

Disinilah tampaknya Tuhan memancarkan cahayanya kepada manusia dan manusia juga mulai memancarkan cahayanya sebagai bagian dari Tuhan. Manusia itu sebenarnya "cuilan" dari pancaran Tuhan sehingga esensi manusia adalah cahaya Tuhan.

Manusia akan dapat mengeluarkan cahayanya ketika ruhnya tidak lagi dikotori oleh pikiran-pikiran keduniawian. Pikiran-pikiran keduaniawian itu akan dapat menghambat proses keluamya cahaya manusia.

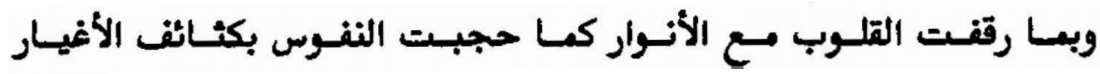


Kadang-kadang hati itu bisa berhenti bersama-sama dengan cahaya, sebagaimana terhalangnya nafsu sebab tebalnya benda-benda makhluk (syahwat).

Adapan menurut para sufi ada dua penghalang yang dapat merintangi atau menghijab manusia kepada Allah yaitu:

1) Hijab nurani, yaitu berupa ilmu, dan ma'rifat. Maka perintah yang berupa ilmu dan ma'rifat itu dinamakan penghalang nurani. Ini yang menyebabkan dia terhalang untuk berjalan kepada Allah, karena ilmuilmu ma'rifat tersebut dijadikan pokok tujuan. Jadi putus ditengah jalan, tidak sampai kehadirat Allah.

2) Hijab kegelapan. Hijab kegelapan ini berupa adat kebiasaan dan syahwat. Ini juga yang menyebabkan terhalangnya berjalan kepada Allah, dikarenakan hatinya masih terpengaruh oleh keinginan nafsu yang masih menguasai dirinya.

Hati itu dapat silau oleh berbagai macam cahaya, sebagaimana nafsu dengan kegelapan benda, sedang Allah dibalik itu semua.

\section{Simpulan}

a. Cahaya-cahaya Manusia Pilihan

Allah swt sebenarnya menciptakan manusia-manusia yang memiliki cahaya yang paling terang diantara manusia. Mereka inilah para Nabi dan para wali Allah. Mereka diberikan mandat oleh Allah untuk memberikan penerangan terhadap kegelapan yang terjadi pada manusia.

Para wali Allah memiliki cahaya Allah berupa ilmu yang dapat menyinari hati umat manusia, akan tetapi cahaya para wali tersebut ditutup oleh Allah sebagai rahmat atau kasih sayang kepada orang-orang mu'min lainnya, sebab jika rahasia-rahasia kewalian tersebut diberikan kepada seseorang pasti akan mewajibkan bagi orang yang terbuka itu kewajibankewajiban yang mungkin tidak dapat melaksanakannya, dengan demikan 
berarti ia terjerumus kedalam lembah dosa yang sangat durhaka. Dan dikhawatirkan baginya untuk selalu menggunakan kewaliannya itu untuk digunakan semaunya sendiri demi popularitasnya sebagai seorang yang memiliki kelebihan;

"Allah menutupi cahaya hati dengan bermacam-macam keadaan lahiriyah karena memuliakannya untuk diberikan tidak secara terangterangan atau (khawatir) dipanggil untuk sebuah popularitas.

“Maha suci Allah yang tidak menjadikan bukti (tanda) terhadap para walinya, kecuali sekedar bukti pengenalan kepadanya, dan tidak akan sampai kepada mereka kecuali orang yang Allah telah menghendaki menyampaikan kepada Allah"

\section{b. Cahaya Muhammad saw}

Nabi Muhammad saw adalah manusia yang paling dekat dengan Allah. Cahayanya paling bersinar diantara manusia di dunia. Dia adalah cahaya di atas cahaya manusia (أنت نسور فوق نسو). Cahaya Nabi Muhammad saw dibaratkan dengan ungkapan فـوت نـوت lain dengan cahaya Allah yang diungkapkan dalam al-Qur'an dengan (نور على نور) memakai lafadz على فوق). Dalam bahasa Arab lafadz فـوق dan lafadz على dibedakan maknanya. فلى فـوق mempunyai arti diatas akan tetapi untuk benda yang menempel, misalnya itu berarti ada sebuah kitab berada diatas bangku, kitab tersebut menempel diatas bangku. Sedangkan makna على itu juga diatas akan tetapi tidak menempel, seperti المـباح على المتـب ada sebuah lampu diatas bangku. Jadi posisi lampu itu di atas tapi tidak menempel. Sekarang bagaimana kita menyikapi arti dari lafadz diatas. Makna yang pertama adalah cahaya Allah adalah cahaya yang bisa memberi sinar kepada seluruh makhluk yang ada di dunia ini termasuk memberi cahaya kepada cahaya Muhammad saw dan juga memberikan cahaya pada dzat-Nya sendiri. Sedangkan cahaya Muhammad itu adalah cahaya di atas cahaya semua makhluk akan tetapi tidak bisa memberikan cahaya kepada Allah. 
Posisi cahaya Muhammad adalah menempel paling atas diantara cahaya manusia. Sedangkan cahaya Allah berada di atas cahaya semua makhluk bagaikan lampu yang berada diatas sebuah ruangan.

Nabi Muhammad diibaratkan sebuah lentera bagi hati manusia. Sebelum manusia diciptakan sebenarnya Allah memancarkan cahayaNya yang kedua yaitu Muhammad, bahkan setelah Adam tercipta di dunia dan ingin menikah dengan Hawa cahaya Muhammad adalah mahar bagi pernikahan keduanya.

\section{c. Cahaya Ruh}

Ruh adalah kutub yang berkilauan cahaya dalam jiwa manusia. Sedang jism adalah kutub yang penuh kegelapan. Adapun nafs (jiwa) ialah zona netral yang dijadikan ajang tarik menarik manusia. Ia adalah media yang bias mengantarkan kepada Allah, tapi ia juga bisa menjadi media untuk menggulung manusia dengan jilatan api jahanam.

Gerak ruhani,ialah gerak menuju Allah (liqa'ullah) atau mendekat kepada-Nya (taqamub). Perlu diingat bahwa gerak ruhani dan jasmani itu tentu berbeda. Perbedaan itu antara lain karena keduanya terjadi di alam yang berbeda dengan hukum-hukum yang berbeda. Namun, bagaimanapun juga ada persamaan antara keduanya.

Gerak ruhanipun demikian juga, meski unsur yang terlibat jauh lebih banyak dan komplek. Gerak ruhani butuh kepada jiwa (nafs) sebagai tempat gerak fitrah sebagai penggerak, akal sebagai "bahan utama" gerak dan terkuasainya hawa nafsu dan setan. Ruh juga menjadi sentral terwujudnya penginderaan manusia baik penginderaan lahir maupun batin. Manusia menjadi sempurna berkat ruh yang sebenarnya merupakan pancaran Allah. Jadi esensi diri manusia itu sebenarnya adalah pancaran Allah yang berupa ruh. Al-Qur'an sendiri menggambarkan ruh sebagai persoalan Tuhan, karena memang sifat ruh hampir seperti eksistensi Allah sendiri. Karenanya ruh adalah urusan Allah. 
Dan mereka bertanya kepadamu tentang roh. Katakanlah: "Roh itu termasuk urusan Tuhan-ku, dan tidaklah kamu diberi pengetahuan melainkan sedikit". (QS. al-Israa': 85)

Dengan ruh itulah manusia menjadi memiliki kehendak. Dengan ruh itu pula manusia mempunyai ilmu pengetahuan.dengan ruh pula manusia menjadi bijaksana, memiliki perasaan cinta dan kasih sayang, serta berbagai sifat ke-Tuhanan di dalam kehidupan manusia.

Kemudian dia menyempurnakan dan meniupkan ke dalamnya roh (ciptaan)-Nya dan dia menjadikan bagi kamu pendengaran, penglihatan dan hati; (tetapi) kamu sedikit sekali bersyukur. (QS. asSajadah: 9)

Maka apabila Aku Telah menyempurnakan kejadiannya, dan Telah meniup kan kedalamnya ruh (ciptaan)-Ku, Maka tunduklah kamu kepadanya dengan bersujud. (QS. al-Hijr: 29)

\section{Daftar Pustaka}

Azhari. Kautsar.1995. Ibn Al-Arabi (Wahdat al-Wujud dalam Perdebatan). Paramadina, Jakarta.

Al-Ghazali, 1964. Misykat Al Anwar (dalam mutiara Ihya' Ulumuddin. Wicaksana. Semarang.

Bayong, 2006. Ilmu Kebumian dan Antariksa. Rosda Karya. Bandung

Beiser. Athur. 1981. Concepts of Modern Physics. Mc-Graw-Hill.

Baqir, 1997. Falsafatuna. Mizan. Jakarta.

Ensiklopedi sains dan kehidupan. 2003. Tarity Samudra Berlian. Jakarta.

Gribbin. 2005. Fisika Modem. Gramedia. Jakarta.

Haderani, 1972. Ilmu Ketuhanan. CV. Amin. Surabaya.

Halliday \& Resnick, 1994. Fisika. Erlangga. Jakarta. 
Hurlock, 2000. Psikologi Perkembangan bagi Manusia. Sutabaya.

Kenneth S. Krane 1982. Modem Physics. John willey and Sons, Inc: New York

Khan Sahib. 1995. Tasawuf, Apa dan Bagaimana. Raja Grafindo Persada. Jakarta.

Mahdi Al-Ashify. 1977. Hawa Nafsu. YAPI. Bangil.

Mahmud, Mustafa. 1987. Al-Wujud wal Adam. Media Idaman.

Pasya. Fuad.2004. Dimensi Sains Al-Qur'an. Tiga Serangkai. Solo.

QS. al-Baqarah(2): 3, 17, 20

QS. an-Nur: 35

QS. Yunus: 5

QS. Nuh: 16

QS. an-Naba': 13

QS. an-Nisa: 174

QS. at-Taghabun: 8

QS. at-Thuur: 35

QS. al-Hadiid: 9

QS. al-Israa': 85

QS. as-Sajadah: 9

QS. al-Hijr: 29

Ulul Albab, Vol. 9 No. 1, 2008 